УДК 81'38:659.13, ББК 81-5:76.0, ГРНТИ 16.21.33 + 19.21.07, КОД ВАК 10.02.19

И. В. Высочкая

Новосибирск, Россия

\title{
ТИПЫ КОММУНИКАТИВНЫХ НЕУДАЧ В РЕКЛАМЕ
}

В статье характеризуется рекламная коммуникативная модель и рассматриваются на основании методов лингвистического описания $u$ интерпретации типь коммуникативных неудач в современной российской рекламе. Непосредственное лингвистическое наблюдение и системное описание языкового материала дополняется дискурсным и медиалингвистическим анализом. Исследование носит интерпретащионновероятностный характер. Рекламная коммуникация характеризуется как массовая, использующая широкий арсенал форм воздействия на адресата и средств распространения информации, как акционная, агональная, манипулятивная. Поскольку она является частью не только маркетинговой, но и культурной сферы общественной жизни, то наряду с коммерческой обладает коммуникативной, эстетической и этической ияенностью. Коммуникативная неудача трактуется как низкая узнаваемость и запоминаемость рекламного произведения, а также его непритягательность, общественное неодобрение и противоречие нормам морали и права. Причинами неудач в сфере рекламы могут быть недостаточный учет характера адресата, некорректное использование языковых $u$ изобразительных средств, а также прагматические факторы. На основании анализа рекламных произведений разных жанров типология коммуникативных неудач в рекламе (с возможностью выделения двух уровней деления) может быть представлена следующим образом:

1. Диссонанс ментальных миров коммуникантов:

а) противоречие культурной традиции;

b) использование прецедентных феноменов, актуализирующих негативную историческую память, вызывающих негативные ассощуиаџии или нарущающих нормы этики;

с) нераспознавание прецедентных феноменов. 
2. Характер коммуникативного текста:

а) использование конструкиий с языковым отрицанием;

b) двусмисленность;

с) ненормативность.

3. Обстоятельства общения:

а) неудачный выбор места размещения рекламы;

b) нарушение композиционной целостности рекламного произведения (оторванность от контекста);

c) «навязанный» контекст;

d) некорректное оформление.

Все три типа коммуникативных неудач подвергаются правовому регулированию статьями Федерального закона. Юридизаџия рекламной коммуникации обеспечивает механизмы воздействия общества на индустрию рекламы и создает условия для перевода акционной коммуникативной модели в интеракциионую.

Ключевые слова: коммуникативная неудача, ментальные миры коммуникантов, коммуникативный текст, обстоятельства общения.

Сведения об авторе: Ирина Всеволодовна Высоикая, доктор филологических наук, профессор кафедры семиотики и дискурсного анализа Новосибирского национального исследовательского государственного университета. 630090, г. Новосибирск, ул. Пирогова, д. 1, к. 1221. E-mail: vysotskya@mail.ru.

\section{V. Vysotskaya}

Novosibirsk, Russia

\section{TYPES OF COMMUNICATION FAILURES IN ADVERTISING}

The article describes an advertising communicative model and examines the types of communicative failures in modern Russian advertising basing on methods of linguistic description and interpretation. Direct linguistic observation and systemic description of linguistic material is complemented by discourse and medialinguistic analysis. The study is of an interpretative nature. Advertising communication uses many forms of influence on the addressee and means of dissemination of information, such as promotional, agonal, and manipulative. Since it is part of not only marketing but also the cultural sphere of public life, it also has a communicative, aesthetic and ethical value along with a commercial one. Communicative failure is interpreted as low recognition and memorability of the advertising work, as well as its unassailability, public disapproval and contradiction with the norms of morality and law. The reasons for failures in advertising can be 
insufficient account of the nature of the addressee, incorrect use of linguistic and visual means, as well as pragmatic factors.

Basing on the analysis of advertising works of different genres, the typology of communicative failures in advertising can be represented as follows:

1. Dissonance of the mental worlds of communicants:

a) the contradiction of the cultural tradition;

b) the use of precedent phenomena, actualizing negative historical memory, causing negative associations or violating norms of ethics;

c) non-recognition of precedent phenomena.

2. The nature of the communicative text:

a) use of constructions with language negation;

b) ambiguity;

c) non-normality.

3. Circumstances of communication:

a) unsuccessful choice of the location of advertising;

b) violation of the compositional integrity of the advertising work (isolation from the context);

c) «imposed» context;

d) incorrect design.

All three types of communicative failures are subject to legal regulation - articles of the Federal Law. The legalization of advertising communication provides mechanisms for the impact of society on the advertising industry and creates the conditions for translating the communicative communicative model into an interactive one.

Key words: communicative failure, mental worlds of communicants, the communication text, circumstances of communication.

About the author: Irina Vsevolodovna Vysotskaya, Doctor of Philology, Professor of the Chair of Semiotics and Discourse Analysis, Novosibirsk National Research State University. Ul. Pirogova 1, office 1221. Novosibirsk, 630090.E-mail:vysotskya@mail.ru.

Современная реклама представляет собой явление массовой коммуникации, синтезирующее экономические, социальные, культурные, филологические, философские, этические, эстетические, правовые и другие проблемы. Она привлекает внимание яркой «палитрой» средств выразительности и влиянием на жизнь современного общества. Так, по словам, 
Ю. В. Шатина, «мы воспринимаем рекламу не потому, что этого хотим мы, а потому, что этого хочет реклама» [Шатин 2013: 64]. Исследование коммуникативных неудач в сфере рекламы представляется важной задачей.

Понимание коммуникации как деятельности, содержанием которой является обмен информацией для достижения взаимодействия, воплощено в коммуникативной модели [Городецкий 1989], на основании которой реклама может быть охарактеризована следующим образом.

1. Массовая коммуникация определяет характер коммуникантов. Реклама адресована группе потребителей и часто создается авторским коллективом. Только у простейших рекламных текстов автор рекламной идеи самостоятельно воплощает ee, профессиональный подход предполагает специализацию: разработкой идеи может заниматься один из работников отдела сбыла или отдел рекламы, созданием рекламного произведения один дизайнер, но чаще дизайнер и текстовик, если не большой коллектив исполнителей.

2. Обстоятельства общения определяет ряд факторов: разновидность рекламы, канал, время и место ее распространения и проч.

3. Система коммуникативных замыслов в рекламе сложна и неоднородна. Коммуникативная цель привлечения внимания может варьироваться в зависимости от жизненного цикла товара (выход на рынок расцвет - зрелость - упадок): информация о новинке, развитие спроса; напоминание, отстройка от конкурентов и др. Практическая цель определяется когнитивной моделью, формулой товарного мифа [Шатин 2013: 65]. Известная модель Элмера и Левиса (1896) AIDA attention - interest - desire - action (внимание - интерес - желание - действие) дополняется в модели AIDMA таким важным звеном, как мотив. Желая продать товар (или услугу), рекламодатель продает идею, апеллирует к рациональным, эмоциональным, социальным мотивам. В этом - заведомая манипулятивность рекламы.

4. Коммуникативные процессы характеризуются активностью адресанта и предполагают практические, выгодные ему, действия адресата. Это 
субъектно-объектные, неравноправные отношения, контролируемые субъектом, при которых обратная связь коммуникатора с аудиторией выступает как механизм социального управления [Шарков 2010: 461].

5. Коммуникативный текст может быть моно-, ди- или поликодовым, сверхкратким или достаточно полным, может строиться по определенным правилам, в определенной стилистике, характеризоваться определенным набором языковых средств и т. п.

Итак, рекламная коммуникация может характеризоваться как массовая, использующая широкий арсенал форм воздействия на адресата и средств распространения информации, как акционная, агональная, манипулятивная. Важно, что она является частью не только маркетинговой, но и культурной сферы общественной жизни, поэтому наряду с коммерческой реклама обладает коммуникативной, эстетической и этической ценностью. Коммуникативная эффективность рекламы оценивается по четырем основным критериям: 1) распознаваемость, 2) запоминаемость, 3) притягательная сила рекламы и 4) ее агитационная сила [Ухова 2013: 37].

Коммуникативная неудача последовательно определяется как «недостижение цели коммуникации» [Стернин 2003: 10], как «полное или частичное непонимание высказывания участником коммуникации, то есть неосуществление или неполное осуществление коммуникативного намерения говорящего или пишущего» [Азимов 2009: 99]. Это - «сбой в общении», при котором речевое произведение не выполняет своего предназначения [Городецкий 1989: 23]. Сбой может создавать дискомфорт у одного или обоих коммуникантов, а в некоторых случаях и приводить к конфликту. Интересно, что в определении коммуникативной неудачи как речевого акта, «при котором намерение говорящего (в частности, иллокутивная сила) было неправильно понято слушающим, в результате чего реакция слушающего оказалась неадекватной» [Кронгауз 2001: 345], важной составляющей, маркером неудачи является неадекватная реакция слушающего. Это отчасти снимает вопрос о необходимости понимания всей системы коммуникативных замыслов: 
говорящему важнее адекватная реакция на его сообщение, а не полное понимание его настоящих целей и намерений (за исключением известной ситуации, сводимой к формуле; «Ты меня понимаешь?»). Т. н. «образ желательного результата» оказывается важнейшей составляющей.

Напомним, что применительно к перформативным высказываниям Дж. Остин предложил шесть условий успешного их функционирования (подчеркивая их очевидность): 1) процедура произнесения «определенных слов определенными лицами в определенных обстоятельствах»; 2) возможность («пригодность») для проведения процедуры; 3) «правильность» ее проведения; 4) «полнота» ее проведения; 5) «подлинные» намерения всех коммуникантов; 6) соответствие намерений последующему поведению [Остин 1986: 33].

Используя компоненты коммуникативной модели, можно сказать, что эти условия касаются триады коммуникативный текст + коммуниканты + обстоятельства, качества ее составных частей, качества коммуникативных процессов, системы коммуникативных замыслов и их реализации.

Выделяют коммуникативные неудачи, причиной которых является сам коммуникант и обстоятельства коммуникативного акта [Городецкий 1985: 6772]. Однако при равной ответственности участников коммуникации корректнее говорить об обоих коммуникантах и выделять коммуникативные неудачи, порождаемые: 1 1) устройством языка; 2) различиями говорящих; 3) прагматическими факторами [Ермакова 1993]. Иначе говоря, неудачи могут быть связаны с языковым кодом, коммуникантами и обстоятельствами общения.

Коммуникативная неудача, таким образом, может быть определена как недостижение коммуникативной и/или практической целей, обусловленное диссонансом «ментальных миров коммуникантов» [Мустайоки 2015], обстоятельствами общения или коммуникативным текстом и приводящее к сбою коммуникативных процессов.

Заметим, что четкая дифференциация причин коммуникативной неудачи не всегда возможна, поскольку в ряде случаев причин несколько. Напомним 
также о поликодовом характере рекламного текста, требующем анализа различных его составляющих (визуального и вербального рядов). Коммуникативная неудача может быть связана с любым из них, а также с их соотношением. При составлении типологии коммуникативных неудач предлагаем выделить на первом уровне деления триаду «ментальные миры коммуникантов (1) - коммуникативный текст (2) - обстоятельства общения (3)» с последующей ее детализацией.

\section{1. Коммуникативные неудачи в рекламе, вызванные диссонансом} ментальных миров коммуникантов.

Неудачи этой группы связаны с недостаточным учетом фактора адресата. Это может быть противоречие культурной традиции. Можно утверждать, что большая часть неудач, обусловленных различиями коммуникантов, связана с фоновыми знаниями. Справедливо отмечено, что источниками коммуникативных неудач в рекламе являются прецедентные феномены [Алексеева 2008], вызывающие отрицательные ассоциации (выделены разные причины таких неудач на примере рекламы ресторанного бизнеса).

Противоречие культурной традиции нашей страны - в некорректном использовании исторически значимого образа Родины-матери со знаменитого плаката времен Великой Отечественной войны (И. Тоидзе «Родина-мать зовет!», 1941 год) в рекламном объявлении о наборе в аспирантуру на сайте одного из вузов Новосибирска. Штраф за использование этого образа в рекламе скидок на обувь составил 100 тыс. руб. (НГС. Новости, 28.03.2016).

Примером актуализации негативной исторической памяти в прецедентном высказывании служит кощунственный слоган бани «Освенцим omdblxaem». В настоящее время по этому случаю ведется проверка прокуратуры (Вести-Новосибирск, 16.03.2017). Мы отмечали ранее противоречие нормам этики некоторых рекламных слоганов, которые «могут задеть чувства верующих: Вера. Одежда. Любовь (ТЦ «Аура», Новосибирск); Акция. Чистый четверг. Всем клиентам автомойки скидка - $10 \%$ (Новосибирск). Еще дальше в своем пренебрежении к традиционным 
ценностям зашли банки: Банк вам в помощь (Банк Москвы); Береженого банк бережет (Кредит Европа Банк). В этих слоганах (хочется верить, что только в них!) банк занимает место Бога» [Высоцкая 2014: 46].

Неудача может быть связана и с прецедентным образом. Одна из сотовых компаний при выходе на рынок в серии рекламных материалов использовала образы мафиози. Сложно сказать, каких ассоциаций, позитивных или негативных, у адресатов было больше. На наш взгляд, далеко не каждый потребитель рекламного продукта хотел бы ассоциировать себя с членами итальянской мафии. Интересно, что позже, при смене рекламной стратегии эта компания использовала образы «правдорубов» и ввела тарифы с названиями: «Черныйџ», «Беспредельно черный», «Самыий черный», «Очень черный» и под. О негативных коннотациях этого прилагательного сказано немало (вплоть до требований политкорректной замены его в английском языке в некоторых наименованиях).

Коммуникативные неудачи могут быть обусловлены нераспознаванием прецедентного феномена. Мы обращались ранее [Там же: 57] к тексту радиорекламы:

Каждый день, смотря в зеркало, я думаю: «Что выросло, то выросло». Но совсем недавно я узнала о новой сыворотке... Теперь мои ресницы стали более длинными, пушистыми <..> Заказать сыворотку для ресниц вы можете...

«Что выросло, то выросло» - прямая цитата из кинофильма «Мистер Икс» (по мотивам оперетты «Принцесса цирка»), отсылающая к комическому диалогу хозяйки Каролины и Пеликана:

- И вот этот поросеночек рос-рос...

- Poc-poc...

- И выросла большая...

- И выросла большая... Э-э, что выросло?!

- Что выросло, то выросло. 
Возможно, взрослые радиослушатели легко узнают этот текст-источник в рекламе сыворотки для ресниц, однако в студенческой аудитории это никому не удалось.

В связи с этим наиболее одиозными представляются слоганы рекламной кампании «Полное собрание низких цен» (Леруа Мерлен): Слово о по́лке Игоря; Кафельный цзветочек; Очарованный краник; Господин из санфаянса; Дядя в ванне; Гордость и водоснабжение.

Это своеобразные шарады, в которых обыгрываются прецедентные названия произведений древнерусской, русской классической и зарубежной литературы (С. Аксаков, Н. Лесков, И. Бунин, А. Чехов, Дж. Остен), но разгадает их не каждый. Поэтому возникает вопрос не только об уместности, но и о коммуникативной эффективности подобной рекламы. Представляется, что в подавляющем большинстве случаев такой путь создания слогана объясняется только субъективными предпочтениями копирайтеров (без учета возможной реакции целевой аудитории и явно без проверки на фокус-группе).

Заметим, однако, что чаще рекламисты не рискуют, не гонятся за оригинальностью и поэтому эксплуатируют самые узнаваемые прецедентные феномены - в расчете на самого массового адресата.

2. Коммуникативные неудачи в рекламе, вызванные характером коммуникативного текста.

Неудачи этого типа обусловлены самим устройством языка. Все коммуникативные риски, связанные с поликодовым текстом рекламного произведения, вряд ли можно систематизировать в рамках данной работы. Отметим некоторые из них.

Исследователи обращают внимание на недопустимость использования конструкций с языковым отрицанием, приводя в качестве примера рекламу банковской услуги в московском метро (2006 год) со слоганом: Жить $в$ кредит-не повредит [Реклама... 2011: 44]. Визуальный ряд содержит изображение молодых людей, летящих по голубому небу на кредитной карте, словно на ковре-самолете. Недостатком можно считать логическое решение «не 
по положительному, а по отрицательному признаку: не повредит» [Реклама... 2011: 44].

Критику могут вызвать и некоторые метафоры. Так, в рекламе санитарногигиенического средства для ног использованы изображения, где «из пиджака с сорочкой и галстуком вместо головы торчат голые ноги» и женский образ «с торчащей ногой вместо головы» [Реклама... 2011: 48]. Надпись гласит: Здоровые ноги - это Ваше лицуо. Почему же за ногами Вы ухаживаете менее ревностно? По мнению исследователей, «неэстетичность и парадоксализм изображения, как и предметно-понятийная несогласованность, логическая клочковатость утверждения и отсутствие предметной и понятийной базы для создания метафоры, к которой стремились авторы, являются факторами ослабления эмоционально-смыслового мотива» [Реклама... 2011: 48]. Подчеркнем, что парадоксальная и эпатажная стилистика часто вызывают неприятие.

Ср. также рекламу сэндвича с надписью «КОРМИМ ГРУДЬЮ» и изображением двух булочек, соединенных таким образом, чтобы они напоминали женскую грудь. Ассоциации с куриной грудкой, из которой, возможно, изготовлен чикен тендер сэндвич, весьма отдаленные.

Реализацией стратегии парадокса на уровне языка является ориентация на двусмысленность, широко распространенная в современной коммуникации, в том числе и рекламной. Случаи обыгрывания многозначности и омонимии языковых единиц в рекламном тексте отмечены многими исследователями.

Эффект обманутого ожидания, или «двойного дна», создает и намеренный конфликт значений вербального и визуального рядов, актуализирующий семантическую диффузность. В некоторых случаях эффект получается забавным: рядом с текстом «Заработай больше, чем в банке!» (ForexClub, Москва, баннер в метро) нарисована стеклянная банка с денежными купюрами внутри, что позволяет воспринимать словоформу в банке как форму предложного падежа от существительного банка, а не банк. Иногда это сбивает с толку, как в случае с рекламным плакатом «Отведай ухи» (трактир-клуб 
«Разгуляй», Самара), на котором изображены уши (по мысли авторов, видимо, $y x u)$. А иногда - воспринимается на грани приличия, как в случае с рекламой сети трактиров «Печки-лавочки» (Новосибирск), слоган которой гласит: Приелась русская? У нас есть и другая! Слова русская и другая контекстуальные субстантиваты, то есть прилагательные, относящиеся к слову кухня. Однако на рекламном плакате пояснение (Кухни мира в новом меню) отделено от приведенного выше вопросно-ответного единства, причем между двумя частями текста помещен рисунок с изображением двух девушек (в русском национальном и экзотическом костюмах). Это позволяет воспринимать слова русская и другая как срединные субстантиваты со значением лица женского пола и уводит далеко от кулинарных ассоциаций.

Этот же прием использован в рекламном ролике пенсионного фонда России: отец рассказывает сыну, что он тоже выбирал: «темненькая была таинственной и казалась привлекательной», но он выбрал «белую и официальные отношения» (реклама ПФРФ - темненькая и белая зарплата).

Впрочем, подобные рекламные произведения могут быть оценены поразному разными социальными группами. Об эротическом и сексуальном подтексте в современной российской рекламе сказано и написано немало.

Коммуникативная неудача может быть обусловлена некорректным использованием языковых средств. Прежде всего это связано с лексикой ограниченного употребления. Ср. два рекламных объявления сети магазинов бытовой техники: Большая халява в большие выходные; Празднуем скидками 50\%. В первом использовано жаргонное слово, во втором - гипнотический потенциал цифры.

Неоднозначны названия «Шмотка» (магазин одежды), «Мобилка» (ремонт телефонов), «Клевый смайл» (подростковая стоматология), содержащие слова, ненормативные для литературного языка, хотя и вполне понятные массовой аудитории.

В этой связи отметим рекламные материалы имиджевой кампании «С каждым клиентом мы находим общий язык» (Альфа-Банк, 14.06.2016), 
посвященной 25-летнему юбилею «Альфа-Банка», основанной на социальной дифференциации речи. Можно в целом высоко оценить прием стилизации, использованный в серии телевизионных роликов (с обобщающим сборным роликом), однако вне контекста целой серии некоторые из роликов («Хипстер», «Модный блоггер») могут вызвать только непонимание, особенно при восприятии на слух, когда строка с переводом на литературный язык не видна.

Орфографические и пунктуационные ошибки в рекламе могут быть непреднамеренными: Аккустика - и преднамеренными: Чюдо (буква «ю» служит фоном для рисунка, графическим акцентом). И те, и другие могут восприниматься неоднозначно. Однако преднамеренные на фоне непреднамеренных утрачивают свою оригинальность. Отметим также междусловное наложение с искажением орфографического облика: в слове визитка-агидка спрятано гид, а в наименовании «Клуб ПАТИФОН 80» читатель должен, вероятно, распознать английское слово в русской трансляции пати.

Если создатели рекламы намеренно выбирают ненормативность как рекламную стратегию, она должна быть достаточно яркой, заметной. «Мы хотели сделать такую рекламу, чтобы люди переставали водить машину в тот момент, когда видят наши щиты», - отметила в беседе с корреспондентом Sostav.ru директор по маркетингу телеканала Кира Ласкари, комментируя рекламную кампанию, коммуникативным элементом которой стал слоган в виде логотипа-графемы и рифмы к слову «Пятница»: Пора жениц̧а!, Побежали numaųa! и т. п. (Sostav.ru, 01.10.2013). В создании парадоксального текста задействованы ресурсы не только фонетики (звук [ц] обозначен на письме буквой «це» вместо нормативного сочетания букв «тэ» и «эс»): Будем радоваца!, - но и окказионального словообразования: Будем хохотащฺа!

Эпатажной языковой стратегией может считаться использование обсценной лексики (достаточно вспомнить рекламную кампанию сети «Евросеть» с рифмующимся глаголом), лексических или графических эвфемизмов и прочих недвусмысленных намеков: И вдруг, ГЛЯДь, какая куртка! (Lenta.ru 29.11.2015); ХУдЕЕТЕ без денег? Выручим (Sibkray.ru, 
22.09.2014). Рекламная кампания «Факты без косметики» (Омск здесь, 18.04.2014) в Омске была построена на пропуске средней части слова, которое могло читаться двояко: и как хороший, хорошая, хорошие (теоретически), и иначе. Надписи на щитах с «дырками» гласили: В Омске $x \ldots \check{\text { }}$ бюджет $(x \ldots я$ экология, $x \ldots e$ дороги) и содержали указание на возрастные ограничения аудитории: $16+$.

Заметим, что с введением 1 июля 2014 года т. н. «закона о запрете мата в СМИ» (так в прессе называют комплекс поправок в российском законодательстве) и с активным вниманием общества к проблеме сквернословия подобной рекламы стало значительно меньше. И хотя она не исчезла совсем, но изменила формат и место размещения: к примеру, тейблтент с изображением совы и надписью: $H u$ г. Новосибирске в октябре 2015 года.

Необычность текста (наряду с повторяемостью) является важным условием привлечения внимания. Однако «приедаются» даже самые необычные элементы текста, поэтому языковые приемы в рекламе требуют постоянного обновления. К примеру, уходит в прошлое злоупотребление латиницей, чрезвычайно распространенное несколько лет назад. Двусмысленность и ненормативность современного рекламного текста становятся настолько ожидаемыми и прогнозируемыми, что это существенно снижет их коммуникативную эффективность.

\section{3. Коммуникативные неудачи в рекламе, вызванные} обстоятельствами общения.

Это тип неудач обусловлен прагматическими, или дискурсивными, факторами. Важным оказывается место размещения рекламы. Так, во время одной предвыборной кампании рекламные материалы кандидата (без какихлибо изменений) были размещены командой его конкурента на мусорных баках, у входа в подвал, на крышках канализационных люков и в других «непрезентабельных» местах (пример И.Ю. Качесовой) с тем, чтобы в сознании избирателей образ этого кандидата ассоциировался с чем-то неприятным. 
Поэтому неудачной представляется попытка размещения рекламных объявлений под ногами - на асфальте, часто по соседству с лужами, мусором, грязью. Неоднозначно с этих позиций можно оценить и т. н. «туалетные стикеры» (в московских аэропортах и др. общественных местах).

Весьма странно выглядит в некоторых случаях и «живая реклама»: люди с рекламными щитами на груди и спине. Известно, что глаза человека мощный ай-стопер (от англ. eye-stopper - ‘то, что останавливает глаз’), поэтому так популярны крупные планы на обложках журналов. Лицо и глаза «оператора подвижных рекламных поверхностей» (так официально называют людей с рекламными щитами) в большей степени, на наш взгляд, привлекают внимание, чем расположенный на плакате текст, тем более что он оказывается ниже уровня глаз. Специалисты подчеркивают, что такой способ рекламирования только в России «ассоциируется с маргинальными личностями, кое-как прикрученными к ним картонками и рекламой какого-нибудь локального полумертвого бизнеса», в то время как в Европе «успешно развиваются целые агентства, в арсенале которых красивые типовые конструкции и персонал, одетый в униформу» (Новый маркетинг, 27.10.2009). Здесь важно учесть климатические особенности. Вид людей со щитами (к примеру, у станций метро в Москве), часами стоящих на улице, пусть и с чашкой чая в руках, часто не вызывает ничего, кроме жалости.

Еще одна серьезная проблема - нарушение композиционной целостности рекламного произведения, или оторванность от контекста (о которой мы уже упоминали в связи с серией ТВ-роликов «Альфа-Банка»). Ярким примером парадоксальной стилистики считается рекламная кампания первой линии бизнес-класса национального авиаперевозчика Швейцарии. В ней было использовано «изображением беспечного обнаженного мужчины, плавающего в небесах», причем «на первых рекламных объявлениях были изображены только его ноги, затем через некоторое время появились плакаты с другими частями тела, пока, наконец, на последних объявлениях он явился целиком» [Шатин 2013: 74]. Кампания считается успешной, поскольку «все билеты в 
бизнес-класс были проданы, несмотря на то, что перевозчик увеличил количество кресел на 30\%» [Шатин 2013: 74].

Подобный прием используется и в России. Приведем в качестве примера две рекламные кампании. Первая связана с ребрендингом телекоммуникационного оператора связи. На первом этапе появилась серия плакатов со словами с позитивной окраской (радость, здоровье, красота), в которых была выделена необычная буква «эр». На втором этапе эта буква уже употреблялась в наименовании компании (Ростелеком), логотипом которой она и оказалась. Это привело, однако, к одностороннему восприятию знака, хотя разработчики наделяли его более сложным значением, изображая букву, «которая по форме напоминает то ли ухо, то ли половину сердечка» (Sibnet.ru, 20.09. 2011).

Другой пример связан с т. н. «зонтичной» рекламной кампанией одного из операторов мобильной связи, включающей серию телевизионных роликов и баннеров наружной рекламы. Сначала появились баннеры с вырванными из контекста интригующими фразами, написанными крупными буквами: Синдром дефицичта скорости?; Неврозис мобиле? и под. На некоторых из них были и более мелкие надписи, не очень, впрочем, информативные, к примеру: Неврозис мобиле - мобильный невроз (вымышленное заболевание). ОАО «МегаФон». В Новосибирске баннер с надписью Скорость исиеляет был установлен при въезде в город и сбивал с толку водителей, поскольку на этом участке действовал уже режим ограничения скорости. Кроме того, в рекламном тексте можно было выявить и дополнительный смысл (слово скорость (жарг.) может обозначать наименование легких наркотиков), и на этом основании было предложено запретить рекламу и снять этот баннер.

Заметим, что сюжет сборного телевизионного ролика «Исцеление скоростью», завершающего рекламную кампанию, сводился к тому, что «медленный мобильный Интернет приводит к неврозу и депрессиям, способствуя развитию симптомов» (Advertology: Наука о рекламе, 05.09.2013) заболевания «неврозис мобиле», а единственным лекарством, способным 
побороть эту болезнь, служит переход на сверхскоростной мобильный Интернет от рекламируемого оператора связи. Вид страдающих от недостатка скорости людей напоминает состояние наркотически зависимых и в целом вызывает, на наш взгляд, негативные ассоциации.

Еще один прагматический фактор коммуникативной неудачи - т. н. «навязанный контекст», то есть неудачное соседство рекламного объявления. Так, сочетание надписей реплик: Приглашаем на работу: вакансий нет создает эффект «иллокутивного самоубийства». Ср. также соединение названий соседних вывесок: керамический мед; хороший служебный вход (вывеска магазина «Хороший» + надпись: Служебнылй вход).

Иногда каламбурный эффект создается за счет некорректного оформления текста:

\section{НАРКОМАНИЯ}

ВЫХОД ЕСТЬ

\section{АЛКОГОЛИЗМ}

Коммуникативная неудача может быть связана с разными особенностями исполнения (шрифт, цвет и др. технические составляющие) рекламного произведения. В Новосибирске, к примеру, были жалобы водителей на ослепляющую световую рекламу, мощность которой существенно превышала допустимые нормативы и создавала аварийные ситуации на дорогах (ВестиНовосибирск, 02.02.2017).

Языковая игра активизирует наше метаязыковое поведение, заставляя обратить внимание на то, как именно написана вывеска. В качестве прецедентного знака в рекламе может использоваться математический знак, например + («плюс»): Вклад «Доходный +». Одни +bl (кредитное партнерство «Финансовая компания», Новосибирск). Слово плюс заменено соответствующим знаком, слово плюсы записано с помощью математического и лингвистических символов (букв). Вряд ли такое употребление можно считать удачным, поскольку красный знак на белом фоне ассоциируется с 
медицинским красным крестом, а не с «плюсом». Ср. также: ++к (Компания ТТК, Новосибирск).

Перевод утилитарного речевого поведения в семиотическое повышает вероятность того, что рекламный текст будет замечен адресатом. Для производителя рекламного произведения важно, однако, чтобы критическое восприятие формы рекламного текста не распространилось на его содержание.

Юридизация рекламной коммуникации обеспечивает механизмы воздействия общества на индустрию рекламы. Указанные выше типы коммуникативных неудач во многом регулируются законодательством. С фактором массового адресата связаны отдельные положения Федерального закона от 13.03.2006 № 38-Ф3 (ред. от 28.07.2012 с изменениями, вступившими в силу с 01.01.2013) «О рекламе»: запрещается «использование бранных слов, а также непристойных и оскорбительных образов, сравнений и выражений, в том числе в отношении расы, национальности, профессии, социальной категории, возрастной группы, пола, языка, государственных символов (флага, гимна, герба), религиозных символов», а также национального и мирового культурного наследия (ст. 4.6). Характер коммуникативного текста регулируется этим же законом, не допускающим «использование иностранных слов и выражений», которое может привести к искажению смысла рекламной информации (ст. 4.5), а также «законом о запрете мата в СМИ». Некоторые положения закона о рекламе касаются правил размещения рекламы, то есть обстоятельств общения. Таким образом, все описанные выше три типа коммуникативных неудач подвергаются правовому регулированию.

Подведем итоги. Коммуникативная неудача - это низкая узнаваемость и запоминаемость рекламного произведения, а также его непритягательность, общественное неодобрение и противоречие нормам морали и права. Причинами неудач могут быть недостаточный учет характера адресата, некорректное использование языковых и изобразительных средств, а также прагматические факторы. 
На основании анализа рекламных произведений типология коммуникативных неудач в рекламе (с возможностью выделения второго уровня деления) может быть представлена следующим образом.

1. Диссонанс ментальных миров коммуникантов (недостаточный учет фактора адресата):

• противоречие культурной традиции;

- использование прецедентных феноменов, актуализирующих негативную историческую память, вызывающих негативные ассоциации или нарушающих нормы этики;

- $\quad$ нераспознавание прецедентных феноменов.

2. Характер коммуникативного текста:

• использование конструкций с языковым отрицанием;

- двусмысленность;

- $\quad$ ненормативность.

3. Обстоятельства общения:

• неудачный выбор места размещения рекламы;

• $\quad$ нарушение композиционной целостности рекламного произведения (оторванность от контекста);

• «навязанный» контекст;

- $\quad$ некорректное оформление.

ЛИТЕРАТУРА

1. Азимов Э. Г., Щукин А. Н. Новый словарь методических терминов и понятий (теория и практика обучения языкам). М., 2009.

2. Алексеева M. С. Прецедентные феномены как источник коммуникативных неудач в рекламе предприятий ресторанного бизнеса. Политическая лингвистика. 2008. Вып. 2 (25). C. $122-126$.

3. Высочкая И. В. Стилистика рекламного текста: прецедентность и интердискурсивность. Новосибирск:, 2014.

4. Городецкий Б. Ю., Кобозева И. М., Сабурова И. Г. К типологии коммуникативных неудач. Диалоговое взаимодействие и представление знаний. Новосибирск, 1985. 
5. Городецикий Б. Ю. Компьютерная лингвистика: моделирование языкового общения. Новое в зарубежной лингвистике. М., 1989. Вып. 24. С. 5-31.

6. Ермакова О. П., Земская Е. А. К построению типологии коммуникативных неудач (на материале естественного русского языка). Русский язык и его функционирование: коммуникативно-прагматический аспект. М., 1993. С. 90-157.

7. Кронгауз М. А. Семантика. М., 2001.

8. Мустайоки A. C. Коммуникативные неудачи сквозь призму потребностей говорящего. Язык и мысль: Современная когнитивная лингвистика. М., 2015. С. 543-557.

9. Остин Дж. Л. Слово как действие. Новое в зарубежной лингвистике. М., 1986. Вып. 17. С. 22-130.

10. [Реклама...] Реклама: язык, речь, общение / Под ред. О. Я. Гойхмана, В. М. Лейчика. М., 2011.

11. Стернин И. А. Возрастное коммуникативное поведение как предмет изучения. Возрастное коммуникативное поведение. Воронеж, 2003. Вып. 1. С. 4-11.

12. Ухова Л. В. Теоретические проблемы исследования эффективности рекламного текста: автореф. дис. ... д-ра филол. наук. Ярославль, 2013.

13. Шарков Ф. И. Коммуникология: основы теории коммуникации. М., 2010.

14. Шатин Ю. В. Неориторика. Новосибирск, 2013.

\section{REFERENCES}

1. Azimov E. G., Shchukin A. N. New Dictionary of Methodical Terms and Concepts (Theory and Practice of Teaching Languages) [Novyj slovar' metodicheskih terminov i ponyatij (teoriya i praktika obucheniya yazykam)]. Moscow, 2009.

2. Alekseeva M.S. Precedent phenomena as a source of communicative failures in advertising of restaurant business enterprises. Political Linguistics [Precedentnye fenomeny kak istochnik kommunikativnyh neudach $\mathrm{v}$ reklame predpriyatij restorannogo biznesa. Politicheskaya lingvistika], 2008. Vol. 2 (25). P. 122-126.

3. Vysotskaya I. V. Stylistics of the advertising text: precedence and interdiscursivity [Stilistika reklamnogo teksta: precedentnost' i interdiskursivnost']. Novosibirsk, 2014.

4. Gorodetsky B. Yu., Kobozeva I. M., Saburova I. G. On the typology of communicative failures. Dialogue interaction and representation of knowledge [K tipologii kommunikativnyh neudach. Dialogovoe vzaimodejstvie i predstavlenie znanij]. Novosibirsk, 1985.

5. Gorodetsky B. Yu. Computer linguistics: modeling of language communication. New in foreign linguistics [Komp'yuternaya lingvistika: modelirovanie yazykovogo obshcheniya. Novoe v zarubezhnoj lingvistike]. Moscow, 1989. Vol. 24. P. 5-31. 
6. Ermakova O. P., Zemskaya E. A. On the construction of the typology of communicative failures (on the basis of the natural Russian language). Russian language and its functioning: communicative and pragmatic aspect $[\mathrm{K}$ postroeniyu tipologii kommunikativnyh neudach (na materiale estestvennogo russkogo yazyka). Russkij yazyk i ego funkcionirovanie: kommunikativnopragmaticheskij aspect]. Moscow, 1993. P. 90-157.

7. Krongauz M. A. Semantics [Semantika]. Moscow, 2001.

8. Mustajoki A.S. Communicative failures through the prism of the speaker's needs. Language and thought: Modern cognitive linguistics [K postroeniyu tipologii kommunikativnyh neudach (na materiale estestvennogo russkogo yazyka). Russkij yazyk i ego funkcionirovanie: kommunikativno-pragmaticheskij aspect]. Moscow, 2015. P. 543-557.

9. Austin J. L. The word as an action. New in foreign linguistics. [Slovo kak dejstvie. Novoe v zarubezhnoj lingvistike]. Moscow, 1986. Vol. 17. P. 22-130.

10. [Advertising ...] Advertising: language, speech, communication [[Reklama...] Reklama: yazyk, rech', obshchenie] / Ed. O. Ya. Goichman, V. M. Leichik. M., 2011.

11. Sternin I. A. Age-related communicative behavior as a subject of study // Age-related communicative behavior [Vozrastnoe kommunikativnoe povedenie kak predmet izucheniya// Vozrastnoe kommunikativnoe povedenie]. Voronezh, 2003. Vol. 1. P. 4-11.

12. Ukhova L. V. Theoretical problems of investigating the effectiveness of advertising text: the author's abstract. Dis. Dr. Philol. N. [Teoreticheskie problemy issledovaniya ehffektivnosti reklamnogo teksta: avtoref. dis. d.-ra filol. nayk]. Yaroslavl, 2013.

13. Sharkov F. I. Communicology: the fundamentals of the theory of communication [Kommunikologiya: osnovy teorii kommunikacii]. Moscow, 2010.

14. Shatin Yu. V. New rhetorics [Neoritorika]. Novosibirsk, 2013.

\section{ИСТОЧНИКИ}

1. Альфа-Банк снял ремейк легендарной кампании «С каждым клиентом мы находим общий язык» (Альфа-Банк, 14.06.2016). URL:https://alfabank.ru/press/news/2016/6/14/1.html.

2. В Петербурге рекомендовали запретить рекламную «глядь» (Lenta.ru 29.11.2015). URL: https://lenta.ru/news/2015/10/29/glyad/.

3. В Посольстве Израиля в Новосибирске назвали «недалеким» слоган «Освенцим отдыхает» (Вести-Новосибирск, 16.03.2017).

URL: http://www.nsktv.ru/news/obshchestvo/v_posolstve_izrailya_v_novosibirske_nazvali_nedalyekim_ slogan_osventsim_otdykhaet_160320170920/.

4. Калинин И. Тест: запретная пошлость (НГС. Новости, 28.03.2016). URL: http://news.ngs.ru/articles/50001823/. 
5. «Люди-бутерброды» объединились в рекламное агентство (Новый маркетинг, 27.10.2009). URL: http://marketing.web-standart.net/node/49550.

6. «МегаФон» и Leo Burnett Moscow вместе с Иваном Ургантом исцеляют скоростью (Advertology: Наука о рекламе, 05.09.2013). URL: http://www.advertology.ru/article117271.htm.

7. Пастухова Ю. «Ростелеком» меняет бренд (Sibnet.ru, 20.09. 2011). URL: http://info.sibnet.ru/article/314551/.

8. Провокационную рекламу РЕН ТВ в Омске сдирали, ругаясь матом (Омск здесь, 18.04.2014). URL: http://omskzdes.ru/society/24359.html.

9. Светодиодные экраны на ночных улицах слепят новосибирских водителей (ВестиНовосибирск, 02.02.2017).

URL: http://www.nsktv.ru/news/city/svetodiodnye_ekrany_na_nochnykh_ulitsakh_slepyat_novosibirskik h_voditeley_020220171515/.

10. Телеканал Пятница! призвал «радоваца» (Sostav.ru, 01.10.2013). URL: http://www.sostav.ru/publication/telekanal-pyatnitsa-prizval-radovatsa-5772.html.

11. ФАС заинтересовалась нецензурной рекламой в Новосибирске (Sibkray.ru, 22.09.2014). URL: http://sibkray.ru/news/1/867816/img/favicon.ico.

\section{SOURSES}

1. "Alfa" Bank shot a remake of the legendary campaign "We find common grounds with every client” (“Alfa”Bank14.06.2016). URL:https://alfabank.ru/press/news/2016/6/14/1.html.

2. St. Petersburg recommended banning advertisement eye-catchers (Lenta.ru 29.11.2015). URL: https://lenta.ru/news/2015/10/29/glyad/.

3. The Embassy of Israel in Novosibirsk declared the slogan "Auschwitz is no match" as dumb. (News-Novosibirsk, 16.03.2017). URL:

http://www.nsktv.ru/news/obshchestvo/v_posolstve_izrailya_v_novosibirske_nazvali_nedalyekim_ slogan_osventsim_otdykhaet_160320170920/.

4. Kalinin I. Test. Forbidden obscenity. (NGS. News, 28.03.2016). URL: http://news.ngs.ru/articles/50001823/.

5. "Sandwich -people" united into an advertising agency (new marketing, 27.10.2009). URL: http://marketing.web-standart.net/node/49550.

6. "MegaPhone" and Leo Burnett Moscow in company with Ivan Urgant cure with speed. (Advertology: Science about Advertising, 05.09.2013). URL: http://www.advertology.ru/article117271.htm.

7. Pastuhova Yu. "Rostelecom" rebrands itself (Sibnet.ru, 20.09. 2011). URL: http://info.sibnet.ru/article/314551/. 
8. People in Omsk swore when tearing down provocative advertising by REN-TV (Omsk here, 18.04.2014). URL: http://omskzdes.ru/society/24359.html.

9. LED-displays blind drivers on night streets of Novosibirsk (News-Novosibirsk, 02.02.2017).

URL:http://www.nsktv.ru/news/city/svetodiodnye_ekrany_na_nochnykh_ulitsakh_slepyat_novosibi rskikh_voditeley_020220171515/.

10. "Friday" TV channel called to be "huppy" (Sostav.ru, 01.10.2013). URL:

http://www.sostav.ru/publication/telekanal-pyatnitsa-prizval-radovatsa-5772.html.

FAS got interested in foul-language advertising in Novosibirsk (Sibkray.ru, 22.09.2014).

URL: http://sibkray.ru/news/1/867816/img/favicon.ico. 